\title{
Treatment Efficacy of Dysarthria in Patients with Multiple System Atrophy using Water Resistance Therapy
}

\author{
Hye-Rim Chae ${ }^{\mathrm{a}}$, Seong Hee Choi ${ }^{\mathrm{a}, \mathrm{b}}$, Chul-Hee Choi ${ }^{\mathrm{a}, \mathrm{b}}$ \\ ${ }^{a}$ Graduate Program in Audiology \& Speech-Language Pathology, Daegu Catholic University, Gyeongsan, Korea \\ ${ }^{b}$ Department of Audiology \& Speech-Language Pathology, Institute of Biomimetic Sensory Control, and Catholic Hearing Voice Speech Center, \\ Daegu Catholic University, Gyeongsan, Korea
}

Correspondence: Seong Hee Choi, PhD Department of Audiology and Speech-Language Pathology, Institute of Biomimetic Sensory Control, and Catholic Hearing Voice Speech Center, Daegu Catholic University, 13-13 Hayang-ro, Hayang-eup, Gyeongsan 38430, Korea

Tel: $+82-53-850-2542$

Fax: +82-53-359-6780

E-mail: shgrace67@gmail.com

Received: April 20, 2020

Revised: September 5, 2020

Accepted: September 15, 2020
Objectives: Multiple System Atrophy (MSA) is atypical parkinsonian syndrome (APS) affecting respiration, phonation, resonance, and articulation, which is characterized by a mixed type of dysarthria involving hypokinetic, ataxic and spastic. However, there are still very limited speech interventions for MSA, and these demonstrate contrasting effects. The purpose of this study was to investigate the efficacy of water resistance therapy (WRT) of dysarthria in patients with multiple system atrophy. Methods: A total of 9 patients with MSA-C (cerebellar type) (5 males and 4 females) underwent WRT once per week for 6 weeks. Aerodynamic, acoustic, and auditory-perceptual evaluation were performed before and after voice therapy to determine the efficacy of WRT. In addition, outcomes were compared based on disease duration (less than 4 years and more than 4 years), before and after therapy. Results: Significant improvement in aerodynamic, acoustic, and auditory - perceptual evaluation was found following WRT. After therapy, in aerodynamic analysis, increased VC, MPT and reduced Psub were observed. Significant improvements were also observed for $\mathrm{CPP}, \mathrm{L} / \mathrm{H}$ ratio and reduced Jitt, $\mathrm{PPQ}, \mathrm{SPPQ}, \mathrm{vF0}$, Shim, APQ, sAPQ, vAm, STD, NHR, $\sigma C P P$, and $\sigma \mathrm{L} / \mathrm{H}$ ratio. In addition, in auditory-perceptual analysis, harsh voice, strained-strangled voice, pitch fluctuations, vocal tremor, prolonged phonemes, and speech intelligibility were improved. Moreover, significantly reduced SAPQ, vAm \& $\sigma C P P$ were seen in the less than 4-year group, while significant improvement in APQ was observed in the more than 4-year group. Conclusion: Accordingly, significantly positive effects were found in respiration, phonation, and articulation changes following WRT for patients with MSA. WRT may be useful speech therapy for improving dysarthria in patients with MSA.

Keywords: Multiple system atrophy, Dysarthria, Water resistance therapy, Treatment efficacy
다계통위축증(Multiple System Atrophy, MSA)은 파킨슨증 (parkinsonism), 소뇌성 운동 실조증(cerebellar ataxia)과 함께 자 율신경 기능 장애를 나타내는 원인 불명의 진행성 신경 퇴행성 질 환이다(Beyer \& Ariza, 2007; Spillantini et al., 1998; Wakabayashi et al., 1998). MSA는 일반적으로 기저핵(basal ganglia), 피질뇌간로 (corticobulbar tract) 및 소뇌(cerebellum)의 손상으로 인해 과소운 동형(hypokinetic), 경직형(spastic), 실조형(ataxic) 요소를 포함하 는 혼합형 마비말장애를 나타내며(Kluin et al., 1996) 특히, 실조형
마비말장애가 두드러진다고 보고되었다(Gilman et al., 2008). 파킨 슨병(Parkinson disease, PD)과 파킨슨플러스 증후군들과 비교하 였을 때, PD와 진행성 핵상 마비(Progressive Supranuclear Palsy, PSP)에 비해 말과 음성에 미치는 영향이 가장 심하게 나타난다(Rusz et al., 2015).

또한, 뇌간(brainstem)의 변성으로 인해 천명(stridor), 수면 관련 호흡장애, 호흡 부전과 같은 호흡 장애가 질병 초기 단계부터 나타 나는데(Benarroch, 2007; Glass, Josephs, \& Ahlskog, 2006), 이는 
$\mathrm{MSA}$ 환자들이 겪는 주요 증상 중 하나이며 갑작스러운 사망과 관 련이 있다(Flabeau et al., 2014; Tada et al., 2009). 천명(stridor)은 성 대의 근긴장의 결과로서 성대 외전의 문제로 인해 초래된다(Hayashi et al., 1997; Bannister, Gibson, Michaels, \& Oppenheimer, 1981). 의문핵(nucleus ambiguus)의 퇴행으로 후윤상피열근(posterior cricoarytenoid muscle)이 위축되어 호기근인 갑상피열근(thyroarytenoid muscle)이 흡기 시에 활성화되는 성대의 비정상적인 움직 임 패턴은 후두 협착을 초래한다(Bannister et al., 1981, Isono et al., 2001). 이러한 후두의 신경병리학적 문제들이 결국 MSA의 폐활량 (Vital Capacity, VC)과 호흡근 강도 감소에 영향을 미친다(Wang et al., 2014).

$\mathrm{MSA}$ 는 우세한 증상에 따라 파킨슨병 특징을 가진 파킨슨 아형 (parkinsonian variant of multiple system atrophy, MSA-P)과 소뇌 실조형 특징을 가진 소뇌 아형(cerebellar variant of multiple system atrophy, MSA-C)으로 분류된다(Gilman et al., 2008).

MSA-P는 부정확한 자음, 거친 음성, 조음 붕괴, 단음도, 과도한 음도 변이 및 음도 일탈 등 $\mathrm{PD}$ 와 유사한 음성 특징을 보이는 반면, $\mathrm{MSA}-\mathrm{C}$ 는 음소 연장, 지나친 음도 변이와 강도 변이, 음성진전, 청지 각적으로 인식되는 흡기(audible inspiration)와 같은 말음성 특징 이 두드러짐이 보고되었다(Kim et al., 2010; Rusz et al., 2015, 2019). 이러한 음질의 저하는 후두 근육의 통제되지 않는 움직임과 성대 긴장의 변이 및 불완전한 성대 폐쇄로 발생하며 마비말장애의 청지 각적 인상에도 영향을 준다(Rusz et al., 2015, 2019).

순수 과소운동형(hypokinetic) 마비말장애를 보이는 $\mathrm{PD}$ 와 달리 질병의 빠른 진행과 도파민 치료에 잘 반응하지 않는다고 알려져 있으며(Schrag, Ben-Shlomo, \& Quinn, 1999), 양측 시상하부핵 뇌 심부자극술(deep brain stimulation, DBS)과 같은 수술적 치료 효 과도 임상적 증거가 없다고 보고되었다(Zhu et al., 2014). 또한, 호흡 장애를 치료하기 위해 지속적 양압기(continuous positive air pressure, CPAP), 보툴리눔독소 주입술이나 기관절개술(tracheosto$\mathrm{my})$ 이 사용되고 있으나 연구자마다 효과는 상반되었다(Iranzo, 2005; Iranzo et al., 2004; Merlo et al., 2002).

한편, 현재까지 MSA는 약물 치료나 수술적 치료 외에 증상을 완 화시키는 것을 목적으로 언어치료 효과가 보고되었다. 국내에서는 MSA 환자를 대상으로 집중 말운동치료인 SPEAK OUT! ${ }^{\circledR}$ 을 실시 한 연구가 보고되었으며(Park, 2018), 국외에서는 클리어 스피치 (clear speech)와 리실버만 음성치료(Lee Silverman Voice Treatment, LSVT)효과가 보고되었다(Countryman, Ramig, \& Pawlas, 1994; Skrabal et al., 2020). 연구결과, MSA 환자들은 SPEAK OUT! ${ }^{\circledR}$ 과 LSVT 후 최대발성지속시간(Maximum Phonation Time, MPT)
과 음성강도가 증가하였으며, 조음 정확도 및 단음도가 개선되어 말명료도가 개선되었다(Countryman et al., 1994; Park, 2018). 일 반적으로 마비말장애는 신경학적 손상으로 인하여 호흡, 발성, 공 명, 조음체계의 구조나 기능에 문제를 보이는데, LSVT와 같은 총체 적 음성치료 기법들은 말산출과 관련된 호흡, 발성, 공명, 조음 모두 를 종합하여 음성산출 전반에 걸친 치료기법을 의미한다(Stemple, 1993). 국내에서는 최근 신경학적 질환인 $\mathrm{PD}$ 를 대상으로 Chae, Choi, Choi와 Lee (2019)가 물저항발성을 이용하여 PD의 성대 근 육의 움직임을 활성화시키고 성대 운동을 촉진시켜 강직된 성대 근 육을 유연하게 함으로써 신경학적 음성장애 환자의 음성 개선에 긍정적인 효과가 있다고 보고하였다.

물저항 치료(Water Resistance Therapy, WRT)는 최근 가장 널 리 사용되는 총체적 음성치료 방법으로 반폐쇄성도훈련(SemiOccluded Vocal Tract Exercise, SOVTE) 중 하나이다. 공기 중에서 발성하는 공기저항 공명튜브(resonance tube)와 달리 물에서 튜브 로 발성하는 방법으로 유연한 실리콘 튜브를 사용하는데 물의 깊 이에 따라 물의 저항이 달라지며 성도에 미치는 영향도 달라진다 (Choi, 2017; Echternach et al., 2020; Saldías et al., 2020).

WRT는 과다기능(hyperfunctional) 및 과소기능적(hypofunctional) 음성장애 환자 모두에게 사용이 가능한데, 튜브를 얕게 물 에 넣을 경우 낮은 저항을 제공하여 과다기능적 음성장애 환자에 게 용이하며, 물에 깊게 튜브를 넣을 경우 성문 폐쇄를 돕기 위해 높 은 저항을 유발하여 과소기능적 음성장애 환자에게 용이하다고 보고되었다(Simberg \& Laine, 2007).

위에서 살펴보았듯이 국내외적으로 아직까지 MSA 환자를 대상 으로 보고된 총체적 음성치료에 대한 효과 연구는 매우 제한적이 다. 또한, 대부분의 마비말장애 치료는 말산출 체계 중 개별적인 호 흡이나 발성 또는 공명 혹은 조음치료에 초점을 두고 이루어진 연 구가 대부분이다.

따라서, 본 연구에서는 총체적 음성치료 기법인 WRT를 이용하 여 MSA 환자를 대상으로 공기역학적, 음향학적 및 청지각적 평가 를 통해 마비말장애 치료 효과를 살펴보고자 한다.

\section{연구방법}

\section{연구대상}

본 연구에서는 신경과 전문의로부터 MSA-C로 진단받고 마비말 장애를 가진 총 9명(남자 5명, 여자 4명, 평균 연령 $60.22 \pm 5.38$ 세) 을 대상으로 하였으며, MSA 환자 중 3명은 약물을 복용하지 않았 고 6 명은 항파킨슨 약물을 복용 중이었으며, 1 명을 제외하고는 최 
근 1년이내 언어치료를 받은 경험이 없었다. 대상자 5 는 연구 시작 1 년 전부터 주 1 회 연하곤란으로 인한 언어치료를 받고 있는 중이었 다. 언어치료를 받고 있음에도 불구하고 발병된 지 오래되어 사전 검사 시 대상자 중 가장 결과가 좋지 않았다. 연구 참여자들의 정보 는 Table 1과 같다.

\section{연구절차}

치료는 2018년 10월부터 11월까지 총 2개월간 주 1 회 간격으로 6 주, 총 6 회 실시하였다. 치료 시간은 1 회기당 40 분으로 1 그룹당 3 명씩 그룹치료를 실시하였으며 항파킨슨 약물을 복용 중인 환자들의 모 든 연구 절차는 약물복용 3 시간 이내에 이루어졌다. 치료에는 내경 $10 \mathrm{~mm}$, 외경 $13 \mathrm{~mm}$, 길이 $35 \mathrm{~cm}$ 의 실리콘 튜브와 $500 \mathrm{~mL}$ 물병을 사 용하였으며 물의 깊이는 $1-2 \mathrm{~cm}$ 에서 $10 \mathrm{~cm}$ 까지 점차 늘려나갔다.

WRT 프로그램은 Table 2 와 같다. 1 회기에서는 프로그램의 1 단 계인 호흡 및 이완훈련을 실시하였다. 얼굴, 목, 등, 가슴을 펴고 올 바른 자세를 유지하고 코로 깊게 숨을 들이마신 후 입으로 내뱉으 며 복식호흡으로 근육을 이완시켰다. 물병에 $1-2 \mathrm{~cm}$ 깊이로 실리콘 튜브를 넣고 입술은 튜브를 감싸/우/ 모양을 만들었다. 코로 숨을 충분히 들이마신 다음 입으로 내쉬면서 15 초 동안 물거품을 낼 수 있도록 유도하였다. 2회기에서는 2단계인 발성을 동반한 물거품 내 기를 실시하였다. /우/ 또는 /후/ 발성과 함께 15초 동안 물거품 내기 를 실시하였는데, 물의 깊이에 따라 느껴지는 신체 변화에 대해 이 야기를 나누도록 하였다. 3 회기에서는 3 단계인 최적음 찾기를 실시 하였는데, 발성 시작부터 끝까지 물거품의 세기가 일정하게 유지되 는 수준의 음성을 최적음으로 설정하여 최적음을 길거나 짧게 발 성하도록 하였다. 4 회기에서는 프로그램의 4 단계인 최적음을 이용 하여 편안한 음-저음-고음 연장 발성과 스타카토 훈련을 실시하였 다. 5 회기 에서는 5 단계인 최적음을 사용하여 활창하기와 멜로디

Table 1. Participants' information

\begin{tabular}{lcccccc}
\hline Participant & $\begin{array}{c}\text { Age } \\
\text { (yr) }\end{array}$ & Gender & Diagnosis & $\begin{array}{c}\text { Duration of } \\
\text { disease (yr) }\end{array}$ & Medications & $\begin{array}{c}\text { History of } \\
\text { speech } \\
\text { therapy }\end{array}$ \\
\hline 1 & 68 & M & MSA-C & 3 & Yes & No \\
2 & 55 & F & MSA-C & 2 & No & No \\
3 & 63 & F & MSA-C & 3 & No & No \\
4 & 58 & M & MSA-C & 2 & Yes & No \\
5 & 63 & M & MSA-C & 9 & Yes & Yes \\
6 & 64 & F & MSA-C & 4 & Yes & No \\
7 & 59 & M & MSA-C & 4 & No & No \\
8 & 62 & M & MSA-C & 5 & Yes & No \\
9 & 50 & F & MSA-C & 3 & Yes & No \\
\hline
\end{tabular}

$\mathrm{M}=$ male; $\mathrm{F}=$ female; $\mathrm{MSA}-\mathrm{C}=$ cerebellar variant of multiple system atrophy.
훈련을 실시하였다. 활창은 저음에서 고음으로, 고음에서 저음으 로 실시하였으며 멜로디 훈련은 '생일 축하', '산토끼' 등 재생시간이 짧은 노래부터 '사랑으로', '만남' 등 재생시간이 긴 노래로 난이도 를 조절하여 가창하기 훈련을 실시하였다. 6 회기에서는 6 단계의 일 반화 훈련을 실시하였다. 실리콘 튜브를 물에 넣고/우/ 발성을 유지 하도록 하고 실리콘 튜브 혹은 물병을 서서히 뺐다. 실리콘 튜브 없 이 /우/ 발성을 하며 음도와 강도를 변화하고, 음절-단어-문장으로 일반화 훈련을 실시하였다(Chae et al., 2019).

\section{자료수집 및 분석}

\section{공기역학적 평가}

치료 효과를 측정하기 위해 Phonatory Aerodynamic System (PAS) 프로그램(Model $6600 \mathrm{KayPENTAX)을} \mathrm{이용하여} \mathrm{치료} \mathrm{전후}$ 공기역학적 평가를 실시하였다. 편안하게 앉은 자세에서 숨을 깊게 들이 마시고 입으로 최대한 내뱉도록 유도하여 폐활량을 측정하였 다. 최대발성지속시간과 호기량(Expiratory Volume), 유성음 산출시 평균 음압(Mean SPL during voicing)은 얼굴에 마스크를 쓴 상태에 서 평상시 편안한음도와강도로 모음//를 최대한 길게 발성하도록 유도하여 측정하였다. 성문하압(Subglottal Pressure, Psub)은 얼굴에 마스크를 쓴 후 튜브를 입 안에 넣어 혀 위에 위치시키고, 편안한 음 도와 강도로/papapapapa/를 3회 반복하여 평균값을 측정하였다.

\section{음향학적 평가}

음향학적 평가를 실시하기 위하여 조용한 검사실에서 대상자의 치료 전후 음성을 녹음하여 자료를 수집하였다. 수집된 자료의 표 본추출률은 $44,000 \mathrm{~Hz}$, 양자화는 $16 \mathrm{bit}$ 였으며 마이크는 대상자의 입과 약 $10 \mathrm{~cm}$ 거리를 유지하였다. 다차원음성 분석기(Multi-Dimensional Voice Program, MDVP) 프로그램(Model 5105, KayPENTAX)을 이용하여 편안한 음도와 강도로 모음 / / / 를 5초간 3 회 연장 발성하여 녹음하였다. 경직형-실조형 마비말장애의 말 특

Table 2. Water Resistance Therapy Program

\begin{tabular}{ll}
\hline & Water resistance therapy program \\
\hline I & $\begin{array}{l}\text { Relaxing and focusing on posture and breathing, Bubbling without } \\
\text { phonation }\end{array}$ \\
II & Bubbling with phonation \\
III & Finding the target voice \\
IV $\quad \begin{array}{c}\text { Advance using the new phonation style (1): sustained phonation } \\
\text { (middle-low-high pitch), staccato }\end{array}$ \\
V Advance using the new phonation style (2): gliding pitches up and down, \\
VI $\quad$ melody \\
\hline
\end{tabular}


징을 평가하기 위해 사용한 음향학적 파라미터는 Table 3 과 같다 (Rusz et al., 2015). 5초 중 안정된 구간 2초를 선택하여 '거친 음성' 관련 파라미터 jitter percent (Jitt), Pitch Perturbation Quotient (PPQ), Smoothed Pitch Perturbation Quotient (sPPQ), Fundamental Frequency Variation (vF0), shimmer percent (Shim), Amplitude Perturbation Quotient (APQ), Smoothed Amplitude Perturbation Quotient (sAPQ), Peak-to-Peak Amplitude Variation (vAm), Noise to Harmonic Ratio (NHR)과 '긴장되고 쥐어짜는 음 성' 관련 파라미터 Degree of Voiceless (DUV), ‘음도 변이' 관련 파 라미터 Standard Deviation of F0 (STD), ‘음성진전’ 관련 파라미터 F0-Tremor Intensity Index (FTRI), Amplitude Tremor Intensity Index (ATRI)를 분석하여 3회 평균값을 측정하였다. 또한, '거친 음성' 관련 켑스트럼 피크 현저성(Cepstral Peak Prominence, CPP), Cepstral Peak Prominence standard deviation ( $\sigma \mathrm{CPP})$, Low/High spectral ratio (L/H ratio), Low to High spectral ratio standard deviation ( $\sigma \mathrm{L} / \mathrm{H}$ ratio)를 측정하기 위하여 Analysis of Dysphonia Speech and Voice (ADSV) 프로그램(Model 5109, KayPENTAX)을 이용하여 켑스트럼 및 스펙트럼 분석을 실시하였다.

모음 연장 발성과 마찬가지로 편안한 음도와 강도에서 유성음으 로 이루어진 표준 문단 ‘5월 5일은 어린이날이에요'(Choi, 2018)를 읽도록 하였으며, 표본추출율은 모두 $44,000 \mathrm{~Hz}$ 에서 Real Time Pitch 프로그램(Model 5121, KayPENTAX)을 사용하여 녹음하였 다. 모음의 지속시간을 측정하기 위하여 Computerized Speech Lab (CSL) 프로그램(Model 4500, KayPENTAX)을 사용하여 전체 문 장 중 첫 번째 어절의 '오', 두 번째 어절의 '오', 세 번째 어절의 '어'의 모음 구간을 선택하여 모음의 지속시간의 평균값을 측정하였다.

\section{청지각적 평가}

$\mathrm{MSA}$ 는 파킨슨증으로 인한 마비말장애 환자의 청지각적 평가로
고안된 선행 연구들을 참고하여 청지각적 평가를 실시하였다. Kim, Lee, Kim, Choi와 Lee (2004), Rusz 등(2015)에 따라 경직형-실조형 마비말장애와 관련된 음성 특성인 '거친 음성' '긴장되고 쥐어짜는 음성', ‘음도 변이’, ‘음성진전', ‘음소 연장', '말명료도’의 청지각적 변 인을 선택하였고, Duffy (2013)의 경직형 마비말장애 요소인 '과다 비성'을 추가하여 총 6 개의 항목으로 평가하였다. 점수는 5점 척도 로 측정하였으며, 0 점은 정상, 1 점은 경도, 2 점은 중도, 3 점은 고도, 4 점은 심도를 의미한다. 평가는 음성장애 평가 및 치료 경력 5년 이상 인 1 급 언어재활사 2 명이 하였으며, 청지각적 평가의 신뢰도 확인을 위해 평가자 간 분석을 실시하였다. 평가자 간 신뢰도는 치료 전 $92.5 \%$, 치료 후 95.7\%였다. 평가가 일치하지 않은 부분은 평가자가 동시에 듣고 논의 후 최종적으로 동의한 수치를 사용하였다.

\section{통계분석}

수집된 자료는 SPSS version 22.0을 이용하여 통계 분석을 실시 하였으며 통계적 유의성은 .05로 하였다. WRT 전후 공기역학적 및 음향학적, 청지각적 평가 결과를 비교하기 위하여 Wilcoxon's signed-ranks test를 시행하여 분석하였다.

\section{연구결과}

\section{공기역학적 평가}

치료 전후 공기역학적 평가 결과는 Table 4 와 같다. 치료 전후 비 교 결과, 폐활량과 최대발성지속시간, 호기량, 성문하압이 통계적 으로 유의한 차이가 있었다 $(p<.05)$.

한편, 질병 진행 기간에 따른 치료 효과를 살펴보기 위하여 평균 생존기간 6-9년을 기준으로(Maaß, Levin, \& Höglinger, 2016) 발병 후 4년 미만은 발병 초기, 4년 이상은 발병 후기 그룹으로 나누어 비 교하였다. 연구결과 발병 초기 그룹에서 호기량이 유의한 차이가

Table 3. List of speech dimensions for spastic and ataxic dysarthria acoustic measures

\begin{tabular}{|c|c|c|}
\hline Deviant speech dimension & Vocal task & Measures \\
\hline \multicolumn{3}{|l|}{ Spastic } \\
\hline 1. Harsh voice & Sustained phonation & 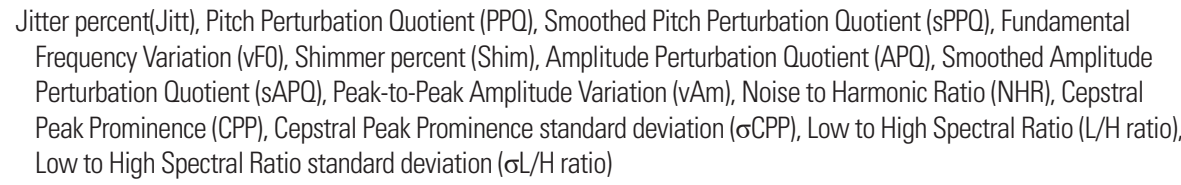 \\
\hline 2. Strained-strangled voice & Sustained phonation & Degree of Voiceless (DUV) \\
\hline \multicolumn{3}{|c|}{ Ataxic } \\
\hline 3. Pitch fluctuation & Sustained phonation & Standard Deviation of FO (STD) \\
\hline 4. Vocal tremor & Sustained phonation & F0-Tremor Intensity Index (FTRI), Amplitude Tremor Intensity Index (ATRI) \\
\hline 5. Prolonged phonemes & Sentence & Vowel duration \\
\hline
\end{tabular}


Hye-Rim Chae, et al. • Water Resistance Therapy for Multiple System Atrophy

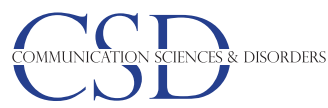

Table 4. Comparisons of aerodynamic measures before and after WRT

\begin{tabular}{|c|c|c|c|c|}
\hline Aerodynamic measure & Group & Before & After & $p$ \\
\hline \multirow[t]{3}{*}{ Vital capacity (Liters) } & Total $(\mathrm{N}=9)$ & $2.44(.90,3.02)$ & $2.40(1.77,3.39)$ & $.021^{*}$ \\
\hline & $\mathrm{DD}<4$ yr $(\mathrm{N}=5)$ & $2.44(.900,2.92)$ & $2.40(1.95,3.51)$ & .078 \\
\hline & $\mathrm{DD} \geq 4$ yr $(\mathrm{N}=4)$ & $2.50(.92,3.12)$ & $2.51(1.60,3.44)$ & .144 \\
\hline \multirow[t]{3}{*}{ Maximum phonation time (sec) } & Total $(\mathrm{N}=9)$ & $17.31(7.37,22.22)$ & $21.30(11.36,29.57)$ & $.015^{*}$ \\
\hline & $\mathrm{DD}<4$ yr $(\mathrm{N}=5)$ & $20.09(16.98,27.35)$ & $22.71(18.77,32.93)$ & .138 \\
\hline & $\mathrm{DD} \geq 4$ yr $(\mathrm{N}=4)$ & $7.73(4.24,18.74)$ & $11.36(9.95,26.12)$ & .068 \\
\hline \multirow[t]{3}{*}{ Mean SPL during voicing (dB) } & Total $(\mathrm{N}=9)$ & $80.88(76.14,86.55)$ & $77.93(76.27,81.63)$ & .110 \\
\hline & $\mathrm{DD}<4$ yr $(\mathrm{N}=5)$ & $76.26(74.88,82.20)$ & $77.93(75.82,79.71)$ & .686 \\
\hline & $\mathrm{DD} \geq 4 \operatorname{yr}(\mathrm{N}=4)$ & $86.55(82.24,99.88)$ & $79.65(76.01,83.85)$ & .068 \\
\hline \multirow[t]{3}{*}{ Expiratory volume (Liters) } & Total $(\mathrm{N}=9)$ & $1.27(.49,2.19)$ & $2.30(1.19,3.25)$ & $.011^{*}$ \\
\hline & $\mathrm{DD}<4 \operatorname{yr}(\mathrm{N}=5)$ & $1.27(0.53,1.95)$ & $2.30(1.19,3.42)$ & $.043^{*}$ \\
\hline & $\mathrm{DD} \geq 4$ yr $(\mathrm{N}=4)$ & $1.31(.40,2.47)$ & $1.93(.58,2.98)$ & .144 \\
\hline \multirow[t]{3}{*}{ Subglottal pressure $\left(\mathrm{cmH}_{2} \mathrm{O}\right)$} & Total $(\mathrm{N}=9)$ & $15.38(9.92,19.06)$ & $8.04(6.91,13.10)$ & $.011^{*}$ \\
\hline & $\mathrm{DD}<4$ yr $(\mathrm{N}=5)$ & $10.71(8.16,14.57)$ & $7.70(6.91,8.06)$ & .080 \\
\hline & $\mathrm{DD} \geq 4$ yr $(\mathrm{N}=4)$ & $19.06(17.21,31.44)$ & $13.10(7.45,14.47)$ & .068 \\
\hline
\end{tabular}

Values are presented as median (25 percentile, 75 percentile/Qaurtiles).

$\mathrm{WRT}=$ water resistance therapy; $\mathrm{SPL}=$ sound pressure level; $\mathrm{DD}=$ duration of disease.

${ }^{*} p<.05$.

있었다 $(p<.05)$.

\section{음향학적 평가}

치료 전후 음향학적 평가 결과는 Table 5 와 Figures 1,2 와 같다. 치료 전후 비교한 결과, '거친 음성' 관련 MDVP 측정치 중 Jitt, $\mathrm{PPQ}, \mathrm{sPQ}, \mathrm{vF} 0$, Shim, $\mathrm{APQ}, \mathrm{sAPQ}, \mathrm{vAm}, \mathrm{NHR}$ 이 치료 전후 통계 적으로 유의하게 감소하였다 $(p<.05) . \mathrm{ADSV}$ 측정치는 $\mathrm{CPP}, \sigma \mathrm{CPP}$, $\sigma \mathrm{L} / \mathrm{H}$ ratio가 치료 전후 통계적으로 유의한 차이가 있었다 ( $p<.05)$. ‘음도 변이” 관련 음향 측정치인 STD가 치료 후 통계적으 로 유의하게 감소하였다 $(p<.05)$. 질병 진행 기간에 따라 발병 초기 그룹은 sAPQ, vAm, $\sigma \mathrm{CPP}$ 가, 발병 후기 그룹은 $\mathrm{APQ}$ 가 통계적으 로 각각 유의한 차이가 있었다 $(p<.05)$.

\section{청지각적 평가}

치료 전후 청지각적 평가 결과는 Table 6과 같다. '거친 음성', '긴 장되고 쥐어짜는 음성', ‘음도 변이', ‘음성진전', ‘음소 연장', ‘말명료 도'가 치료 전후 통계적으로 유의하게 감소하였다 $(p<.05)$. 질병 진 행 기간에 따라서는 발병 초기 그룹에서 ‘음소 연장'과 ‘말명료도' 가 통계적으로 유의한 차이가 있었다 $(p<.05)$.

\section{논의 및 결론}

본 연구에서는 실조형 마비말장애가 두드러진 혼합형 마비말장

애인 MSA 환자 9명을 대상으로 WRT를 실시하여 치료 전후 공기 역학적, 음향학적 및 청지각적 평가 결과의 변화를 통해 WRT가 MSA 환자의 마비말장애에 미치는 치료 효과를 살펴보았다.

먼저, 공기역학적 측정치들의 결과를 살펴보았을 때, 치료 후 통 계적으로 유의하게 폐활량이 증가하였다. 이는 후윤상피열근의 위 축과 갑상피열근의 근긴장 이상으로 인해 비정상적인 호흡근 움직 임이 WRT 후 위축되고 긴장되었던 호흡근을 이완시켜 호흡 능력 이 향상된 것으로 보인다. 최대발성지속시간 또한 치료 후 유의하게 증가하였는데 이러한 결과는 SPEAK OUT! 과 LSVT 후 최대발성 지속시간이 증가하였다는 선행연구(Countryman et al., 1994; Park, 2018)들의 결과와 일치한다. 본 연구에서는 치료 전 최대발성 지속시간은 정상 범주에 속하였으나, 이때의 호기량을 살펴보면 $\operatorname{Kim}$ (2014)의 연구에서 제시된 정상 범주보다 낮게 나타났다. 이는 $\mathrm{MSA}$ 음성 특징인 긴장되고 쥐어짜는 음성과 관련이 있으며 외전 근과 내전근의 비정상적인 움직임으로 인해 발성 시 성문을 강하게 압착하여 호기량이 정상 범주 보다 낮은 것으로 보여진다. 그러나 치료 후 후두 근육이 이완되고 안정화되면서 호기량이 정상 범주 로 증가한 것으로 사료된다. 또한, 성문하압이 치료 후 유의하게 감 소하였다. 이는 MSA 환자들이 질병이 진전됨에 따라 경직형 요소 가 더 증가하여 목소리의 크기가 지나치게 큰 경우가 많고 성대를 쥐어 짜고 발성하는 경향을 보였는데, 지나치게 큰 강도로 인해 성 문하압이 치료 전 높았다가 WRT 후 강도가 정상 범위로 낮아지면 서 성문하압 역시 감소한 것으로 보여진다. 
Table 5. Comparison of Acoustic measures before and after WRT

\begin{tabular}{|c|c|c|c|c|}
\hline Deviant speech dimension acoustic measure & Group & Before & After & $p$ \\
\hline \multicolumn{5}{|l|}{ Spastic } \\
\hline \multicolumn{5}{|l|}{ 1. Harsh voice } \\
\hline \multirow{3}{*}{$\operatorname{Jitt}(\%)$} & Total $(\mathrm{N}=9)$ & $1.414(.873,3.095)$ & $.476(.314,1.133)$ & $.038^{*}$ \\
\hline & $\mathrm{DD}<4$ yr $(\mathrm{N}=5)$ & $1.414(.771,2.819)$ & $.403(.314, .879)$ & .138 \\
\hline & $\mathrm{DD} \geq 4 \operatorname{yr}(\mathrm{N}=4)$ & $1.864(.866,3.223)$ & $.791(.287,1.336)$ & .144 \\
\hline \multirow[t]{3}{*}{$\mathrm{PPO}(\%)$} & Total $(\mathrm{N}=9)$ & $.831(.468,1.718)$ & $.282(.186, .635)$ & $.044^{*}$ \\
\hline & $\mathrm{DD}<4$ yr $(\mathrm{N}=5)$ & $.831(.433,1.518)$ & $.238(.186, .495)$ & .104 \\
\hline & $\mathrm{DD} \geq 4 \operatorname{yr}(\mathrm{N}=4)$ & $1.031(.457,1.791)$ & $.460(.164, .772)$ & .273 \\
\hline \multirow[t]{3}{*}{ SPPQ (\%) } & Total $(\mathrm{N}=9)$ & $1.289(.665,2.366)$ & $.512(.407, .786)$ & $.028^{*}$ \\
\hline & $\mathrm{DD}<4$ yr $(\mathrm{N}=5)$ & $1.289(.899,1.795)$ & $.437(.335, .784)$ & .080 \\
\hline & $\mathrm{DD} \geq 4 \operatorname{yr}(\mathrm{N}=4)$ & $1.729(.576,6.827)$ & $.618(.432, .817)$ & .144 \\
\hline \multirow[t]{3}{*}{$\mathrm{vFO}(\mathrm{Hz})$} & Total $(\mathrm{N}=9)$ & $3.196(1.414,9.034)$ & $1.098(0.729,1.293)$ & $.015^{*}$ \\
\hline & $\mathrm{DD}<4$ yr $(\mathrm{N}=5)$ & $2.311(1.216,3.531)$ & $.752(.627,1.596)$ & .080 \\
\hline & $\mathrm{DD} \geq 4 \operatorname{yr}(\mathrm{N}=4)$ & $9.034(2.509,20.557)$ & $1.137(1.037,1.225)$ & .068 \\
\hline \multirow[t]{3}{*}{ Shim (\%) } & Total $(\mathrm{N}=9)$ & $3.511(2.946,9.686)$ & $2.359(1.960,3.160)$ & $.038^{*}$ \\
\hline & $\mathrm{DD}<4$ yr $(\mathrm{N}=5)$ & $3.496(2.469,7.586)$ & $2.819(1.960,3.809)$ & .345 \\
\hline & $\mathrm{DD} \geq 4$ yr $(\mathrm{N}=4)$ & $6.385(3.273,17.803)$ & $2.196(1.542,2.694)$ & .068 \\
\hline \multirow[t]{3}{*}{$\mathrm{APQ}(\%)$} & Total $(\mathrm{N}=9)$ & $2.781(2.136,6.491)$ & $1.843(1.465,2.380)$ & $.028^{*}$ \\
\hline & $\mathrm{DD}<4$ yr $(\mathrm{N}=5)$ & 2.781 (1.947, 4.892) & $2.205(1.634,2.681)$ & .225 \\
\hline & $\mathrm{DD} \geq 4$ yr $(\mathrm{N}=4)$ & $4.687(2.256,10.820)$ & $1.673(1.178,2.019)$ & $.038^{*}$ \\
\hline \multirow[t]{3}{*}{ SAPQ (\%) } & Total $(\mathrm{N}=9)$ & $6.116(4.140,8.989)$ & $2.510(2.382,3.377)$ & $.008^{* *}$ \\
\hline & $\mathrm{DD}<4$ yr $(\mathrm{N}=5)$ & $6.116(4.322,7.793)$ & $3.328(2.363,3.475)$ & $.043^{*}$ \\
\hline & $\mathrm{DD} \geq 4$ yr $(\mathrm{N}=4)$ & $7.269(3.612,13.248)$ & $2.450(2.386,2.835)$ & .068 \\
\hline \multirow[t]{3}{*}{$\operatorname{vAm}(\%)$} & Total $(\mathrm{N}=9)$ & $16.793(13.340,19.014)$ & $6.379(4.502,7.440)$ & $.008^{* *}$ \\
\hline & $\mathrm{DD}<4$ yr $(\mathrm{N}=5)$ & $15.198(10.318,16.456)$ & $6.379(5.033,7.748)$ & $.043^{*}$ \\
\hline & $\mathrm{DD} \geq 4 \operatorname{yr}(\mathrm{N}=4)$ & $19.014(17.250,26.521)$ & $5.543(3.715,7.165)$ & .068 \\
\hline \multirow[t]{3}{*}{ NHR } & Total $(\mathrm{N}=9)$ & $.132(.124, .244)$ & $.121(.113, .128)$ & $.024^{*}$ \\
\hline & $\mathrm{DD}<4$ yr $(\mathrm{N}=5)$ & $.132(.122, .166)$ & $.121(.118, .134)$ & .176 \\
\hline & $\mathrm{DD} \geq 4$ yr $(\mathrm{N}=4)$ & $.212(.123, .353)$ & $.117(.104, .126)$ & .068 \\
\hline \multirow[t]{3}{*}{$\mathrm{CPP}(\mathrm{dB})$} & Total $(\mathrm{N}=9)$ & $8.939(7.745,12.414)$ & $12.635(12.186,14.377)$ & $.021^{*}$ \\
\hline & $\mathrm{DD}<4$ yr $(\mathrm{N}=5)$ & $11.829(8.824,13.428)$ & $14.360(12.522,15.521)$ & .08 \\
\hline & $\mathrm{DD} \geq 4 \operatorname{yr}(\mathrm{N}=4)$ & $7.745(6.984,11.492)$ & $12.278(11.637,13.832)$ & .144 \\
\hline \multirow[t]{3}{*}{$\sigma \mathrm{CPP}(\mathrm{dB})$} & Total $(\mathrm{N}=9)$ & $1.412(.875,2.212)$ & $.413(.384, .545)$ & $.008^{* *}$ \\
\hline & $\mathrm{DD}<4$ yr $(\mathrm{N}=5)$ & $1.199(.875,1.958)$ & $.542(.426, .587)$ & $.043^{*}$ \\
\hline & $\mathrm{DD} \geq 4 \operatorname{yr}(\mathrm{N}=4)$ & $1.845(.834,2.469)$ & $.389(.354, .408)$ & .068 \\
\hline \multirow[t]{3}{*}{$\mathrm{L} / \mathrm{H}$ ratio (dB) } & Total $(\mathrm{N}=9)$ & $28.925(26.305,33.078)$ & $27.540(26.520,34.899)$ & .678 \\
\hline & $\mathrm{DD}<4$ yr $(\mathrm{N}=5)$ & $29.732(27.455,33.078)$ & $28.277(27.284,34.899)$ & .893 \\
\hline & $\mathrm{DD} \geq 4 \operatorname{yr}(\mathrm{N}=4)$ & $26.658(14.610,34.798)$ & $26.520(25.601,35.189)$ & .465 \\
\hline \multirow[t]{3}{*}{$\sigma \mathrm{L} / \mathrm{H}$ ratio (dB) } & Total $(\mathrm{N}=9)$ & $2.223(1.143,2.450)$ & $1.051(.859,1.172)$ & $.021^{*}$ \\
\hline & $\mathrm{DD}<4$ yr $(\mathrm{N}=5)$ & $1.675(1.005,2.251)$ & $1.151(.670,1.183)$ & .138 \\
\hline & $\mathrm{DD} \geq 4 \operatorname{yr}(\mathrm{N}=4)$ & $2.450(1.417,6.080)$ & $.999(.816,1.150)$ & .068 \\
\hline \multicolumn{5}{|l|}{ 2. strained-strangled voice } \\
\hline \multirow[t]{3}{*}{$\operatorname{DUV}(\%)$} & Total $(\mathrm{N}=9)$ & $.000(.000,3.031)$ & $.000(.000, .000)$ & .180 \\
\hline & $\mathrm{DD}<4$ yr $(\mathrm{N}=5)$ & $.000(.000, .000)$ & $.000(.000, .000)$ & 1.000 \\
\hline & $\mathrm{DD} \geq 4 \operatorname{yr}(\mathrm{N}=4)$ & $3.031(.000,48.106)$ & $.000(.000, .000)$ & .180 \\
\hline
\end{tabular}


Table 5. Continued

\begin{tabular}{|c|c|c|c|c|}
\hline Deviant speech dimension acoustic measure & Group & Before & After & $p$ \\
\hline \multicolumn{5}{|l|}{ Ataxic } \\
\hline \multicolumn{5}{|l|}{ 3. Pitch fluctuations } \\
\hline \multirow[t]{3}{*}{$\mathrm{STD}(\mathrm{Hz})$} & Total $(\mathrm{N}=9)$ & $4.759(2.073,23.083)$ & $1.768(1.086,2.899)$ & $.011^{*}$ \\
\hline & $\mathrm{DD}<4$ yr $(\mathrm{N}=5)$ & $4.003(1.874,6.555)$ & $1.228(.885,2.908)$ & .080 \\
\hline & $\mathrm{DD} \geq 4$ yr $(\mathrm{N}=4)$ & $22.940(3.678,38.056)$ & $2.020(1.542,3.212)$ & .068 \\
\hline \multicolumn{5}{|l|}{ 4. Vocal tremor } \\
\hline \multirow[t]{3}{*}{ FTRI (\%) } & Total $(\mathrm{N}=9)$ & $.360(.000,1.292)$ & $.000(.000, .261)$ & .075 \\
\hline & $\mathrm{DD}<4$ yr $(\mathrm{N}=5)$ & $.381(.000,1.292)$ & $.000(.000, .130)$ & .144 \\
\hline & $\mathrm{DD} \geq 4 \mathrm{yr}(\mathrm{N}=4)$ & $.180(.000,2.872)$ & $.131(.000, .327)$ & .180 \\
\hline \multirow[t]{3}{*}{$\operatorname{ATRI}(\%)$} & Total $(\mathrm{N}=9)$ & $.000(.000,6.343)$ & $.000(.000, .000)$ & .109 \\
\hline & $\mathrm{DD}<4$ yr $(\mathrm{N}=5)$ & $.000(.000,7.401)$ & $.000(.000, .728)$ & .180 \\
\hline & $\mathrm{DD} \geq 4$ yr $(\mathrm{N}=4)$ & $.000(.000,4.433)$ & $.000(.000, .000)$ & .317 \\
\hline \multicolumn{5}{|l|}{ 5. Prolonged phonemes } \\
\hline \multirow[t]{3}{*}{ Vowel duration (sec) } & Total $(\mathrm{N}=9)$ & $.173(.147, .270)$ & $.177(141, .204)$ & .173 \\
\hline & $\mathrm{DD}<4$ yr $(\mathrm{N}=5)$ & $.173(.138, .211)$ & $.165(.123, .181)$ & .500 \\
\hline & $\mathrm{DD} \geq 4 \operatorname{yr}(\mathrm{N}=4)$ & $.219(.146, .332)$ & $.204(.139, .211)$ & .273 \\
\hline
\end{tabular}

Values are presented as median (25 percentile, 75 percentile/ Oaurtiles).

$\mathrm{DD}=$ duration of disease; Jitt=jitter percent; $\mathrm{PPQ}=$ pitch perturbation quotient; $\mathrm{SPPQ}=$ smoothed pitch perturbation quotient; $\mathrm{vF0}=$ fundamental frequency variation; Shim = shimmer percent; $\mathrm{APO}=$ amplitude perturbation quotient; $\mathrm{SAP}=$ = smoothed amplitude perturbation quotient; vAm= peak-to-peak amplitude variation; $\mathrm{NHR}=$ noise to harmonic ratio; CPP-a= cepstral peak prominence in $/ \mathrm{a} / ; \sigma=$ standard deviation; $\mathrm{L} / \mathrm{H}$ ratio-a = low to high spectral ratio in $/ \mathrm{a} / ; \mathrm{DUV}=$ degree of voiceless; STD=standard deviation of fundamental frequency; $\mathrm{FTRl}=\mathrm{fO}$-tremor intensity index; $\mathrm{ATR}=$ amplitude tremor intensity index.

${ }^{*} p<.05,{ }^{* *} p<.01$.

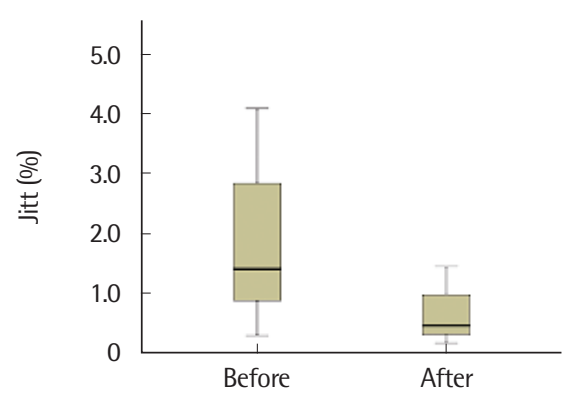

Water resistance therapy

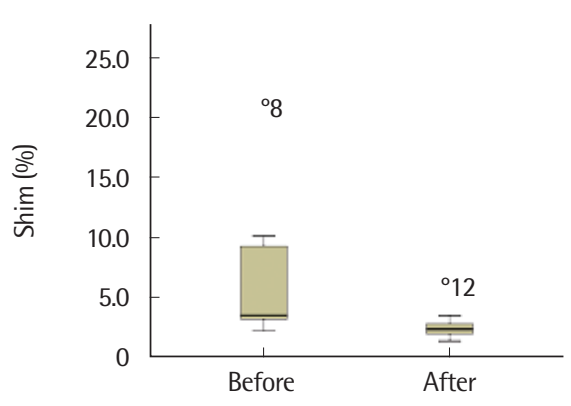

Water resistance therapy

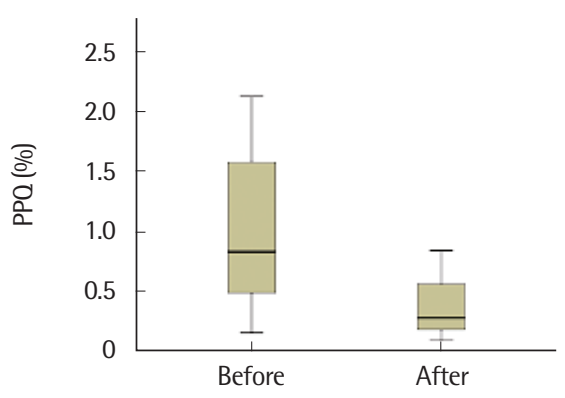

Water resistance therapy

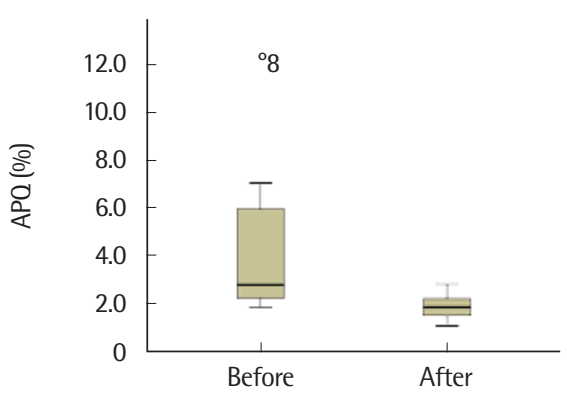

Water resistance therapy

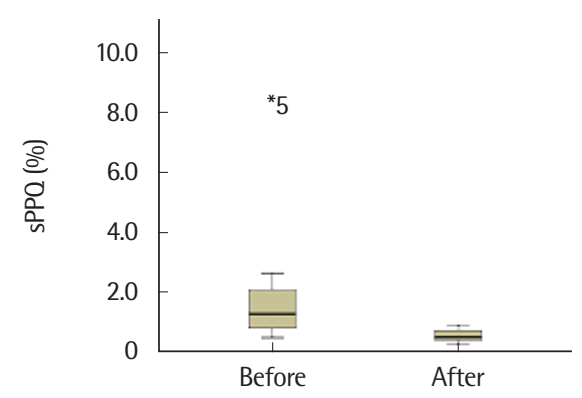

Water resistance therapy

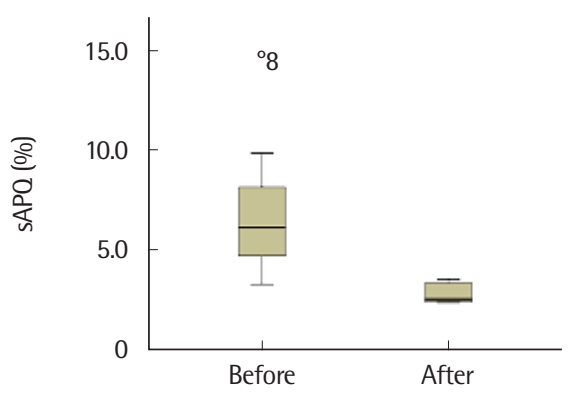

Water resistance therapy

Figure 1. Comparisons of short- and long-term variation parameters of pitch and loudness in MSA patients before and after WRT. MSA=multiple system atrophy; WRT = water resistance therapy; Jitt=jitter percent; $P P Q=$ pitch perturbation quotient; $s P P Q=$ smoothed pitch perturbation quotient; Shim=shimmer percent; $\mathrm{APQ}=$ amplitude perturbation quotient; $\mathrm{SAPQ}=$ smoothed amplitude perturbation quotient. 

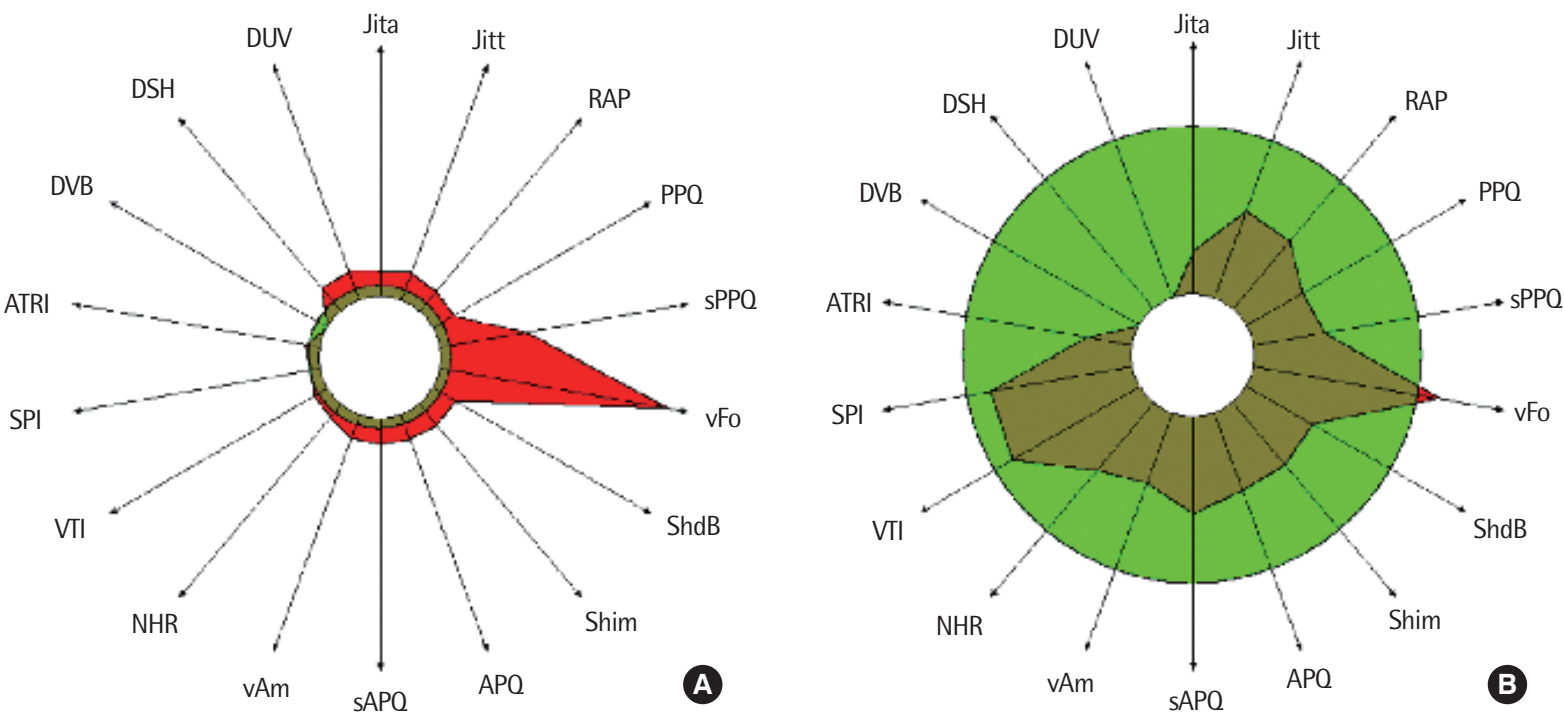

Figure 2. Comparison of MDVP measures before(A) and after(B) WRT in male MSA. MDVP=multi-dimensional voice program; WRT=water resistance therapy; $M S A=$ multiple system atrophy .

Table 6. Comparison of auditory-perceptual measures before and after WRT

\begin{tabular}{|c|c|c|c|c|}
\hline $\begin{array}{l}\text { Deviant speech dimension } \\
\text { auditory-perception measure }\end{array}$ & Group & Before & After & $p$ \\
\hline \multicolumn{5}{|l|}{ Spastic } \\
\hline \multirow[t]{3}{*}{ 1. Harsh voice } & Total $(\mathrm{N}=9)$ & $.50(1.00,2.00)$ & $.00(.00,1.00)$ & $.030^{*}$ \\
\hline & $\mathrm{DD}<4$ yr $(\mathrm{N}=5)$ & $.50(1.00,1.50)$ & $.00(.00, .00)$ & .059 \\
\hline & $\mathrm{DD} \geq 4$ yr $(\mathrm{N}=4)$ & $.50(2.00,2.75)$ & $.25(1.00,1.00)$ & .194 \\
\hline \multirow[t]{3}{*}{ 2. Strained-strangled voice } & Total $(\mathrm{N}=9)$ & $1.00(3.00,4.00)$ & $.00(.00, .00)$ & $.011^{*}$ \\
\hline & $\mathrm{DD}<4$ yr $(\mathrm{N}=5)$ & $3.00(.050,3.50)$ & $.00(.00, .00)$ & .066 \\
\hline & $\mathrm{DD} \geq 4 \mathrm{yr}(\mathrm{N}=4)$ & $1.50(3.50,4.00)$ & $.00(.00, .75)$ & .066 \\
\hline \multirow[t]{3}{*}{ 3. Hypernasality } & Total $(\mathrm{N}=9)$ & $.00(00 ., .50)$ & $.00(.00, .50)$ & .180 \\
\hline & $\mathrm{DD}<4$ yr $(\mathrm{N}=5)$ & $.00(.00, .00)$ & $.00(.00, .00)$ & 1.000 \\
\hline & $\mathrm{DD} \geq 4 \operatorname{yr}(\mathrm{N}=4)$ & $.00(.50,1.75)$ & $.00(.00, .00)$ & .180 \\
\hline \multicolumn{5}{|l|}{ Ataxic } \\
\hline \multirow[t]{3}{*}{ 4. Pitch fluctuations } & Total $(\mathrm{N}=9)$ & $.00(1.00,2.00)$ & $.00(.00, .00)$ & $.026^{*}$ \\
\hline & $\mathrm{DD}<4$ yr $(\mathrm{N}=5)$ & $.00(1.00,1.50)$ & $.00(.00, .00)$ & .102 \\
\hline & $\mathrm{DD} \geq 4 \mathrm{yr}(\mathrm{N}=4)$ & $.25(1.50,2.75)$ & $.00(.00, .00)$ & .109 \\
\hline \multirow[t]{3}{*}{ 5. Vocal tremor } & Total $(\mathrm{N}=9)$ & $.50(2.00,2.00)$ & $.00(.00, .00)$ & $.016^{*}$ \\
\hline & $\mathrm{DD}<4$ yr $(\mathrm{N}=5)$ & $.50(1.00,2.00)$ & $.00(.00, .00)$ & .063 \\
\hline & $\mathrm{DD} \geq 4 \mathrm{yr}(\mathrm{N}=4)$ & $.50(2.00,2.75)$ & $.00(.00, .00)$ & .108 \\
\hline \multirow[t]{3}{*}{ 6. Prolonged phonemes } & Total $(\mathrm{N}=9)$ & $.50(2.00,2.00)$ & $.00(.00,1.00)$ & $.007^{* *}$ \\
\hline & $\mathrm{DD}<4 \mathrm{yr}(\mathrm{N}=5)$ & $1.00(1.00,2.00)$ & $.00(.00, .50)$ & $.034^{*}$ \\
\hline & $\mathrm{DD} \geq 4 \mathrm{yr}(\mathrm{N}=4)$ & $3.00(2.25,3.75)$ & $1.00(.25,1.00)$ & .059 \\
\hline \multirow[t]{3}{*}{ 7. Speech intelligibility } & Total $(\mathrm{N}=9)$ & $1.00(2.00,400)$ & $.00(.00,1.00)$ & $.007^{* *}$ \\
\hline & $\mathrm{DD}<4$ yr $(\mathrm{N}=5)$ & $1.00(1.00,3.00)$ & $.00(.00,0.50)$ & $.039 *$ \\
\hline & $\mathrm{DD} \geq 4 \mathrm{yr}(\mathrm{N}=4)$ & $1.25(3.00,4.00)$ & $.00(.50,1.00)$ & .066 \\
\hline
\end{tabular}

Values are presented as median (25 percentile, 75 percentile/Qaurtiles).

WRT $=$ Water resistance therapy; $\mathrm{DD}=$ duration of disease.

${ }^{*} p<.05,{ }^{* *} p<.01$. 
한편, 유성음 산출 시 평균 음압은 치료 전후 유의한 차이가 없었 는데 이는 치료 후 발병 초기 그룹은 유성음 산출 시 평균 음압이 증가하고, 후기 그룹은 감소하는 경향을 보였다. MSA 환자들은 치 료 전 초기 그룹은 정상 범주에 속하지만(Kim, 2014) 후기 그룹으 로 갈수록 평균 음압이 증가하고 쥐어짜는 음성이 심해진다고 보 고되었는데, 본 연구에 참여한 MSA 환자들은 강도 조절에도 어려 움을 나타내었는데 특히, 후기 그룹에서 큰 목소리로 인해 일상 생 활에서의 불편함을 많이 호소하였다. 대상자 6 의 경우 비정상적인 강도로 인해 집에서 가족과도 거의 대화를 하지 않는다고 하였으 며 치료 전의 유성음 산출 시 평균 음압을 살펴보면 $104.25 \mathrm{~dB}$ 이었 다. 그러나 치료 후 $84.37 \mathrm{~dB}$ 로 정상 규준으로 감소하였다(Kim, 2014). 따라서, 혼합형 마비말장애를 보이는 MSA의 경우 음성 강 도 향상을 목표로 하는 SPEAK OUT! ${ }^{\circledR}$ 이나 LSVT, 클리어 스피치 보다 후두 근육을 이완시켜 음성강도를 적절히 조절할 수 있는 WRT가 더 유용할 것이라 판단된다. 또한, MSA 환자들이 WRT 프 로그램 1단계 호흡 훈련 단계에서 일정한 물거품 세기를 유지하는 것에 많은 어려움을 보였으며, 처음에는 물거품이 폭발적으로 세게 만들어졌다가 점점 약해지는 패턴을 보였고 호기 시간도 짧았다. 따라서 본 연구에서는 치료 시 물거품을 시각적 피드백으로 활용 하여 호기 할 때 호흡 세기를 조절하여 호기 시간을 점차 늘려나갔 다. 예를 들면, 물거품의 세기가 너무 센 경우에는 숨을 내쉴 때 최 대한 약하게 공기를 내뱉도록 유도하고, 물거품이 약한 경우에는 숨을 내쉴 때 공기를 더 많이 내뱉도록 유도하여 물거품 세기를 조 절하도록 하였다.

둘째, 음향학적 측정치들의 결과를 비교하였을 때, WRT 후 단기 간 주파수 변동률과장구간 주파수 변동률 및 장구간 진폭 변동률 이 유의하게 감소하였다. 특히, 치료 후 '거친 음성' 관련 음향학적 측정치 중 음질과 높은 상관관계가 있다고 알려진 Jitt, $\mathrm{PPQ}, \mathrm{sPQ}$, $\mathrm{vF}$, Shim, APQ, sAPQ, vAm, NHR, $\sigma \mathrm{CPP}, \sigma \mathrm{L} / \mathrm{H}$ ratio 측정치가 유의하게 감소하였으며, $\mathrm{CPP}$ 측정치가 유의미하게 증가하였다 (Choi \& Choi, 2016; Lee, Pyo, \& Choi, 2018; Yu, Choi, Choi, \& Choi, 2018). 이는 MSA 환자가 WRT 후 음질이 개선되었으며 단기 간 및 장구간 음도 및 강도 변이가 안정되었다는 것을 의미한다. 뿐 만 아니라 치료 후 거친(harsh) 소리가 통계적으로 유의미하게 감소 하였는데 이는 객관적인 음향학적 지표들이 개선을 뒷받침하는 결 과이며, 발성 시 WRT가 경직된 성대를 이완시키고 성대 진동을 촉 진함으로써 좀 더 규칙적인 성대 진동을 할 수 있도록 도움을 주는 것으로 사료된다.

$\mathrm{MSA}$ 는 외전근인 후윤상피열근이 위축되어 내전근인 갑상피열 근이 성대가 외전할 때 움직이는 비정상적인 움직임을 보이기 때문
에(Guindi et al., 1981; Isono et al., 2001, Alfonsi et al.,2016) 발성 시 성문을 강하게 압착하여 긴장되거나 쥐어짜는 듯한 음성을 산출 한다. DUV는 이러한 음성을 측정할 수 있는 음향학적 지표로 사 용되는데(Rusz et al., 2015), 본 연구에서는 치료 전에 비해 치료 후 $0 \%$ 로 감소하여 WRT가 긴장되거나 쥐어짜는 듯한 음질을 개선시 켜주었음에도 불구하고 통계적으로 유의한 차이는 없었다. 이러한 이유는 대상자들 중 매우 심한 긴장된 쥐어짜는 음질을 가진 대상 자가 전체 대상자 중 $30 \%$ 정도로 개인 간 변이가 심하여 치료 전에 도 쥐어짜는 음성으로 인해 모음 연장 발성 중 음도 일탈이 심하게 나타난 환자는 많지 않았기 때문이다. 하지만 치료 후 청지각적으 로 모음 발성이 훨씬 편안하게 산출되었으며, 연장 발성이 끓기지 않고 음도나 강도가 안정화된 것이 관찰되었다. 특히, 대상자 8 의 경 우 사전 검사 시 DUV 측정치가 $62.121 \%$ 이었는데, 연구 시작 전 현 재 목소리에 어떠한 불편함이 느끼냐는 질문에 작은 목소리를 내 기가 어려우며 음도 일탈이 심하다고 보고하였다. 실제 청지각적으 로도 쥐어짜는 듯한 음성과 음도 일탈의 정도가 빈번하게 관찰되 었으나, 치료 후 이러한 증상이 개선되었으며 대상자 스스로도 목 소리 내기가 편안해졌다고 보고하였다. 한편, 장구간 음도 및 장구 간 강도 변이 파라미터는 신경학적 음성장애 환자의 음성을 평가하 거나 치료 효과를 측정하는 유용한 음향학적 지표라고 하였는데 (Kent et al., 2003), 본 연구에서도 PPQ, sPPQ, vF0, APQ, sAPQ, $\mathrm{vAm}, \mathrm{STD}$ 와 같은 변수들이 치료 전후 유의한 차이를 보여 치료 효 과를 측정하는데 유용한 음향학적 지표였다. 따라서, 추후에는 이 러한 변수들이 MSA의 감별 진단 및 치료 효과 측정에 주요 음향학 적 지표로 유용하게 사용될 수 있을 것이라 사료된다.

또한, '음도 변이' 관련 측정치인 기본주파수의 표준편차(STD) 가 치료 후 유의하게 감소하였는데, 이러한 결과는 근긴장의 위축 으로 비주기적인 움직임을 보이던 성대가 WRT 후 긴장이 이완되 고 성대 움직임이 촉진되어 모음 연장 발성 시 성대 진동이 안정화 되었음을 유추해 볼 수 있다. 따라서, WRT는 실조형 MSA 음성 특 징인 과도한 강도 및 음도 변이 감소에 효과적인 것으로 보여진다. $\mathrm{MSA}$ 를 대상으로 말 음성치료를 실시한 이전의 선행연구에서는 LSVT와 SPEAKE OUT! 실시 후, 강도가 증가하고 단음도가 개선 되었다는 연구결과(Countryman et al., 1994; Park, 2018)가 보고된 반면, 치료 전후 유의한 차이가 없다고 보고한 연구도 있었다. Skrabal 등(2020)은 PD, PSP, MSA를 대상으로 클리어 스피치를 실시한 결과, $\mathrm{PD}$ 는 강도 증가 및 음도 변이가 개선된 반면, $\mathrm{MSA}$ 는 발화 시 강도와 강도 변이 및 음도 변이가 유의한 차이가 없다고 보고하였 다. 하지만, 본 연구에서는 치료 후 음도 변이 및 강도 변이 관련 음 향학적, 청지각적 파라미터들이 유의하게 감소하였으며, 음질이 개 
선되는 것으로 나타났다. 따라서, 이러한 결과는 WRT가 LSVT와 SPEAKE OUT! 과 마찬가지로 MSA의 음성 개선에 효과적인 치 료 방법으로 사용될 수 있음을 시사하였다. 나아가 $\mathrm{PD}$ 를 대상으로 Lax Vox 음성치료를 실시한 결과 음질이 개선되었다는 선행연구 (Chae et al., 2019; da Silva et al., 2020)의 결과와도 비슷한 결과를 나타내어 $\mathrm{WRT}$ 가 $\mathrm{PD}$ 뿐 아니라 실조성 마비말장애를 가진 MSA 환자에게도 효과적인 치료 방법임을 시사하였다.

이외에 본 연구의 대상자들은 주로 음도 및 강도 조절 어려움으 로 인한 부적절한 음도와 강도 문제를 호소하였다. 대상자 6 은 강 도 조절에 어려움을 보여 평상시 소리를 지르는 듯한 큰 강도로만 발성이 가능하였다. 보호자들의 보고에 의하면, 대상자의 부절적 하게 큰 강도로 인하여 가족 간의 비밀이 없을 정도라고 하였으나, 치료 후 발화 강도의 세기가 작아져 정상적인 대화 시 강도 수준에 도달하였으며 강도 변이가 감소하였다. 대상자 5 는 평상시 발성할 때 음도가 점점 상승하여 발성 개시에는 중저음이었으나 발성이 지 속될수록 점점 고음으로 활창하는 듯한 발성을 나타내었다. 보호 자의 보고에 의하면, WRT 후에도 활창하는 듯한 발성은 나타났으 나 치료 전보다 음도 변이가 감소했다고 보고하였다. 또한, 대상자 들이 치료 프로그램을 잘 수행하고 있는지 생체피드백(bio-feedback)을 잘 느끼고 있는지 확인하기 위하여 물의 깊이에 따른 신체 변화에 대해 이야기를 나누었다. 물의 깊이를 얕게 했을 때와 깊게 하였을 때의 신체 느낌을 떠올려 어떤 깊이가 발성할 때 목에 힘이 들어가지 않고 더 편안하게 목소리를 낼 수 있었는지, 안면부 떨림 이 더 잘 느껴졌는지 비교하여 말하도록 하였다. 이 때, 안면부 떨림 을 느끼지 못한 대상자들은 실리콘 마스크를 얼굴에 쓴 상태에서 WRT를 시행하여 안면부 떨림을 충분히 느낄 수 있도록 하였다.

셋째, MSA 환자들은 WRT 후 청지각적으로도 음질이 개선되고 공명과 조음이 개선되었는데, 특히, 청지각적인 평가 항목 중 '거친 음성' '긴장되고 쥐어짜는 음성', ‘음도 변이', ‘음성진전', ‘음소 연장’ 및 ‘말명료도'가 유의하게 개선되었다. 뿐만 아니라 '거친 음성', ‘음 도 변이'에 해당하는 음향학적 변수들도 치료 후 유의하게 개선된 변수였다. '거친 음성'은 MSA의 대표적인 음성 특징 중 하나인데 $\mathrm{WRT}$ 가 성대 진동을 안정화시켜 청지각적으로도 음질이 개선되었 음을 알 수 있었다. ‘음소 연장’은 청지각적으로는 유의한 차이를 보 였는데 문장 읽기에서 어절의 첫 시작 모음의 지속시간이 치료 후 감소하였다. 이는 WRT 후 성대 진동이 유연해지면서 모음 산출의 지속시간도 개선된 것으로 보인다. 또한, ‘음도 변이’가 개선되어 치 료 후 모음 연장 발성에서도 안정된 음도를 유지하였다. 한편, 말명 료도가 유의미하게 증가하여 치료 후 말명료도가 개선되었는데, 이는 WRT가 조음 개선에 직접적인 영향을 미치는 조음 기관의 운
동은 실시하지 않음에도 불구하고 말명료도가 개선되는 효과를 보 였다. 선행 연구에서도 LSVT, SPEAKE OUT! 과 같은 집중치료를 실시한 결과 말명료도가 향상되었다고 보고하였는데(Countryman et al., 1994; Park, 2018), LSVT나 SPEAKE OUT! ${ }^{\circledR}$ 은 치료 목 표가 강도(loudness)의 크기를 크게함으로써 호흡과 발성 및 말명 료도가 개선되는 효과가 있지만, 본 연구에서 WRT의 목표는 물에 서 불기로 발성할 때 MSA 환자들이 물저항운동으로 성도(vocal tract)의 조절을 목표로 한다. 따라서 불기 시 물거품을 발생하게 하 기 위해 필요한 호흡 압력을 형성하고 유지함으로써 호흡의 길이를 연장시키고, 구강압(oral pressure)이 증가하여 결과적으로 성문상 압(supraglottal pressure)이 성문하압보다 높게 되면 성문을 약간 벌림으로써 지나친 근긴장을 완화시킨다. 또한, 경직형 요소 중 비 일관적인 과다비성이 주요 말 특징 중 하나로 보고 되어있는데 (Duffy, 2013) 본 연구결과에서는 발병 후 4년 이상 집단에서 유의 한 차이는 없었으나, 치료 후 비일관적인 과다비성이 감소하는 경 향을 보였다. 뿐만 아니라 성대 진동을 촉진함으로써 성대의 유연 성을 증가시켜 규칙적인 성대 진동을 유도하여 음질을 개선시키고, 불기 시 연구개 운동을 향상시킴으로써 호흡뿐 아니라 발성, 공명, 조음 체계에 긍정적인 영향을 주는 것으로 나타났다.

넷째, MSA 환자의 질병 진행 기간에 따라 치료 효과를 비교한 결과, 발병 초기 그룹이 발병 후기 그룹보다 유의한 개선이 많이 나 타났다. 이는 발병 초기에도 음성치료가 효과적임을 시사하며, 발 병 초기 조기 중재가 MSA 환자의 마비말장애가 악화되는 것을 방 지하고 치료 효과를 높일 수 있는 임상적 시사점을 제공한다. Simberg와 Laine (2007)에 따르면, 신경학적 음성장애 환자에게 WRT 를 실시할 경우 음질 및 강도 저하의 진행을 지연시킬 수 있다고 하 였다. 따라서, 본 연구의 결과로 미뤄보았을 때 WRT가 MSA 발병 초기부터 지속적인 음성치료를 받는다면 음질 저하뿐만 아니라 과 도한 강도 및 음도 변이 등 구어 및 음성 증상들의 진행 속도를 늦추 고 마비말장애를 효과적으로 치료하는 데 유용할 것으로 보인다.

본 연구를 종합해 볼 때 WRT가 발성뿐만 아니라 호흡, 공명, 조 음 개선에 긍정적인 영향을 미치는 것으로 나타났다. WRT는 쉽게 따라하고 실시할 수 있어 가정에서 꾸준히 자가 관리(self-practice) 를 한다면 음성과 의사소통 기능을 좋은 상태로 유지하고 관리할 수 있는 방법이 될 수 있을 것이다.

그러나 본 연구의 제한점으로는 첫째, 대상자 수집의 어려움이 있어 적은 수의 MSA-C 환자만을 대상으로 하였다. 따라서, 추후에 는 더 많은 수의 대상자와 추적 관찰을 통해 장기간 치료 효과를 측 정하고 질병의 진행에 따른 변화 양상을 확인하는 후속 연구가 반 드시 필요할 것이다. MSA-P 환자군 혹은 MSA 하위 유형 모두를 
Hye-Rim Chae, et al. • Water Resistance Therapy for Multiple System Atrophy

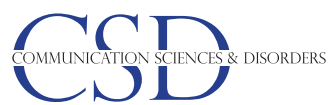

대상으로 실시하여 치료의 효과를 살펴볼 필요가 있다. 더 나아가 MSA-C와 MSA-P의 음성치료 효과를 비교하는 연구 또한 임상적 의의가 있을 것이라 사료된다. 둘째, 성대 진동 검사를 실시하지 못 하여 성대운동을 관찰하지 못하였다. 향후 연구에서는 전기성문파 형검사(electroglottography), 비디오스트로보스코피(videostroboscopy) 또는 초고속 성대 촬영 시스템(High-Speed Video System)을 사용하여 MSA의 성대 기능 특성 혹은 치료 전후 성대의 기능을 객관적이고 정량적으로 분석하여 치료 효과를 입증하는 것이 필요할 것이다. 넷째, 일반적으로 공기 중에서 튜브나 빨대 발 성 시 내경 $3 \mathrm{~mm}$ 가 추천되는데(Titze, 2020), 본 연구에서는 내경 $10 \mathrm{~mm}$, 직경 $35 \mathrm{~cm}$ 의 튜브를 물의 저항을 이용하여 사용하였다. 튜브나 빨대를 물에 넣어서 발성할 경우 물의 저항으로 인해 성도 의 저항이 증가하게 되고(Guzmán et al., 2016; Radolf et al., 2014), 성도의 길이를 연장할 경우 제 1 포먼트를 감소시켜 음원과 성도의 상호작용을 증가시키며 성도를 좁히는 것과 동일하게 리액턴스 효 과를 증가시킬 수 있다(Mills et al., 2017; Titze, 2006; Titze \& Laukkanen, 2007). 추후에는 튜브나 빨대의 직경과 길이 그리고 물의 깊 이를 다양하게 조절하여 그에 따른 효과를 살펴보는 것이 좋겠다. 마지막으로 본 연구결과 WRT 후 젖은 음성이 개선되었으나 직접 적인 연하장애 변수를 측정하지 못하여 연하장애 개선 여부를 살 펴보지 못하였다. 후두는 삼킴에도 중요한 역할을 담당하므로 $\mathrm{WRT}$ 가 삼킴 기능에도 긍정적인 영향을 미칠 것이라 사료된다. 따 라서 향후에는 연하장애 개선 여부도 살펴볼 것을 제안한다.

하지만 이러한 제한점에도 불구하고 본 연구는 WRT와 같은 총 체적 음성치료가 신경학적퇴행성 질환인 MSA 환자의 말산출과 관련된 호흡, 발성, 공명, 조음에 긍정적 효과를 줄 수 있음을 확인 하였으며, 치료 전후 주관적 평가뿐 아니라 객관적 측정치를 제공 함으로써 치료 효과의 증거를 제공하는 데 의의가 있다.

\section{REFERENCES}

Alfonsi, E., Terzaghi, M., Cosentino, G., Tassorelli, C., Manni, R., Pozzi, N., ... \& Fresia, M. (2016). Specific patterns of laryngeal electromyography during wakefulness are associated to sleep disordered breathing and nocturnal stridor in multiple system atrophy. Parkinsonism \& Related Disorders, 31, 104-109.

Bannister, R., Gibson, W., Michaels, L., \& Oppenheimer, D. R. (1981). Laryngeal abductor paralysis in multiple system atrophy. A report on three necropsied cases, with observations on the laryngeal muscles and the nuclei ambigui. Brain: a Journal of Neurology, 104(2), 351-368.
Benarroch, E. E. (2007). Brainstem respiratory control: substrates of respiratory failure of multiple system atrophy. Movement Disorders: Official Journal of the Movement Disorder Society, 22(2), 155-161.

Beyer, K., \& Ariza, A. (2007). Protein aggregation mechanisms in synucleinopathies: commonalities and differences. Journal of Neuropathology \& Experimental Neurology, 66(11), 965-974.

Chae, H. R., Choi, S. H., Choi, C. H., \& Lee, K. (2019). Effects of Lax Vox voice therapy on respiration and phonation in patients with Parkinson's disease. Communication Sciences \& Disorders, 24(3), 785-799.

Choi, S. H. (2017). Semioccluded vocal tract exercise accent method, straw phonation, Lax Vox ${ }^{\circledR}$. The Korean Association for Voice of Performaning Arts, 4, 11-19.

Choi, S. H. (2018). Development of Korean standardized sentences on voice quality evaluation for dysphonia. Audiology and Speech Research, 14(2), 128-142.

Choi, S. H., \& Choi, C. H. (2016). The effect of gender and speech task on cepstral-and spectral-measures of Korean normal speakers. Audiology and Speech Research, 12(3), 157-163.

Countryman, S., Ramig, L. O., \& Pawlas, A. A. (1994). Speech and voice deficits in Parkinsonian plus syndromes: can they be treated. NCVS Status and Progress Report, 6(5), 99-111.

da Silva, J. M. S., Gomes, A. D. O. C., da Silva, H. J., de Vasconcelos, S. J., de Sales, M. D. G. W., \& de Lira, Z. S. (2020). Effect of resonance tube technique on oropharyngeal geometry and voice in individuals with Parkinson's disease. Journal of Voice, https://doi.org/10.1016/j.jvoice.2020.01.025.

Duffy, J. R. (2013). Motor Speech Disorders: Substrates, Differential Diagnosis, and Management (3rd ed., H. H. Kim, M. K. Seo, Y. J. Kim, \& J. H. Yoon, Trans.). Seoul: Pakhaksa.

Echternach, M., Raschka, J., Kuranova, L., Köberlein, M., Richter, B., Döllinger, M., \& Kainz, M. A. (2020). Immediate effects of water resistance therapy on patients with vocal fold mass lesions. European Archives of Oto-Rhino-Laryngology, 1-9.

Flabeau, O., Meissner, W. G., Ozier, A., Berger, P., Tison, F., \& Fernagut, P. O. (2014). Breathing variability and brainstem serotonergic loss in a genetic model of multiple system atrophy. Movement Disorders, 29(3), 388-395.

Gilman, S., Wenning, G. K., Low, P. A., Brooks, D. J., Mathias, C. J., Trojanowski, J. Q., ... \& Kaufmann, H. (2008). Second consensus statement on the diagnosis of multiple system atrophy. Neurology, 71(9), 670-676.

Glass, G. A., Josephs, K. A., \& Ahlskog, J. E. (2006). Respiratory insufficiency as the primary presenting symptom of multiple-system atrophy. Archives 
of Neurology, 63(7), 978-981.

Guindi, G. M., Bannister, R., Gibson, W. P., \& Payne, J. K. (1981). Laryngeal electromyography in multiple system atrophy with autonomic failure. Journal of Neurology, Neurosurgery \& Psychiatry, 44(1), 49-53.

Guzmán, M., Castro, C., Madrid, S., Olavarria, C., Leiva, M., Muñoz, D., ... \& Laukkanen, A. M. (2016). Air pressure and contact quotient measures during different semi-occluded postures in subjects with different voice conditions. Journal of Voice, 30(6), 759-e1.

Hayashi, M., Isozaki, E., Oda, M., Tanabe, H., \& Kimura, J. (1997). Loss of large myelinated nerve fibres of the recurrent laryngeal nerve in patients with multiple system atrophy and vocal cord palsy. Journal of Neurology, Neurosurgery \& Psychiatry, 62(3), 234-238.

Iranzo, A. (2005). Management of sleep-disordered breathing in multiple system atrophy. Sleep Medicine, 4(6), 297-300.

Iranzo, A., Santamaria, J., Tolosa, E., Vilaseca, I., Valldeoriola, F., Martí, M. J., \& Muñoz, E. (2004). Long-term effect of CPAP in the treatment of nocturnal stridor in multiple system atrophy. Neurology, 63(5), 930-932.

Isono, S., Shiba, K., Yamaguchi, M., Tanaka, A., Hattori, T., Konno, A., \& Nishino, T. (2001). Pathogenesis of laryngeal narrowing in patients with multiple system atrophy. The Journal of Physiology, 536(1), 237-249.

Kent, R. D., Vorperian, H. K., Kent, J. F., \& Duffy, J. R. (2003). Voice dysfunction in dysarthria: application of the Multi-Dimensional Voice Program ${ }^{\mathrm{Tm}}$. Journal of Communication Disorders, 36(4), 281-306.

Kim, J. (2014). Korean adult normative data for the KayPENTAX phonatory aerodynamic system model 6600. Phonetics and Speech Sciences, 6(1), 105117.

Kim, H. H., Lee, M. S., Kim, S. W., Choi, S. H., \& Lee, W. Y. (2004). An auditory-perceptual rating scale of dysarthric speech of patients with Parkinsonism. Speech Sciences, 11(2), 39-49.

Kim, Y., Kent, R. D., Kent, J. F., \& Duffy, J. R. (2010). Perceptual and acoustic features of dysarthria in multiple system atrophy. Journal of Medical Speech-Language Pathology, 18(4), 66-71.

Kluin, K. J., Gilman, S., Lohman, M., \& Junck, L. (1996). Characteristics of the dysarthria of multiple system atrophy. Archives of Neurology, 53(6), 545-548.

Lee, S. J., Pyo, H. Y., \& Choi, H. S. (2018). Normative data of cepstral and spectral measures in Korean adults using vowel phonation and passage reading tasks. Communication Sciences \& Disorders, 23(1), 208-216.

Maaß, S., Levin, J., \& Höglinger, G. (2016). Current treatment of multiple system atrophy. Current Treatment Options in Neurology, 18(12), 51.
Merlo, I. M., Occhini, A., Pacchetti, C., \& Alfonsi, E. (2002). Not paralysis, but dystonia causes stridor in multiple system atrophy. Neurology, 58(4), 649-652.

Mills, R., Hays, C., Al-Ramahi, J., \& Jiang, J. J. (2017). Validation and evaluation of the effects of semi-occluded face mask straw phonation therapy methods on aerodynamic parameters in comparison to traditional methods. Journal of Voice, 31(3), 323-328.

Park, Y. (2018). Efficacy of intensive treatment of dysarthria for people with multiple system atrophy. Phonetics and Speech Sciences, 10(4), 163-171.

Radolf, V., Laukkanen, A. M., Horáček, J., \& Liu, D. (2014). Air-pressure, vocal fold vibration and acoustic characteristics of phonation during vocal exercising. Part 1: measurement in vivo. Engineering Mechanics, 21(1), $53-$ 59.

Rusz, J., Bonnet, C., Klempíř, J., Tykalová, T., Baborová, E., Novotný, M., \& Růžička, E. (2015). Speech disorders reflect differing pathophysiology in Parkinson's disease, progressive supranuclear palsy and multiple system atrophy. Journal of Neurology, 262(4), 992-1001.

Rusz, J., Tykalová, T., Salerno, G., Bancone, S., Scarpelli, J., \& Pellecchia, M. T. (2019). Distinctive speech signature in cerebellar and parkinsonian subtypes of multiple system atrophy. Journal of Neurology, 266(6), 1394-1404.

Saldías, M., Guzman, M., Sandoval, G., Vergara, C., Lizana, J., \& Quezada, C. (2020). Water resistance therapy as vocal warm-up method in contemporary commercial music singers. Folia Phoniatrica et Logopaedica, 72(1), 1-12.

Schrag, A., Ben-Shlomo, Y., \& Quinn, N. P. (1999). Prevalence of progressive supranuclear palsy and multiple system atrophy: a cross-sectional study. The Lancet, 354(9192), 1771-1775.

Simberg, S., \& Laine, A. (2007). The resonance tube method in voice therapy: description and practical implementations. Logopedics Phoniatrics Vocology, 32(4), 165-170.

Skrabal, D., Tykalova, T., Klempir, J., Ruzicka, E., \& Rusz, J. (2020). Dysarthria enhancement mechanism under external clear speech instruction in Parkinson's disease, progressive supranuclear palsy and multiple system atrophy. Journal of Neural Transmission, 1-10.

Spillantini, M. G., Crowther, R. A., Jakes, R., Cairns, N. J., Lantos, P. L., \& Goedert, M. (1998). Filamentous $\alpha$-synuclein inclusions link multiple system atrophy with Parkinson's disease and dementia with Lewy bodies. Neuroscience Letters, 251(3), 205-208.

Stemple, J. C. (1993). Voice Therapy, Clinical Studies. St. Louis, MO: MosbyYear book. 
Hye-Rim Chae, et al. • Water Resistance Therapy for Multiple System Atrophy

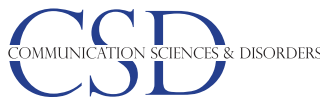

Tada, M., Kakita, A., Toyoshima, Y., Onodera, O., Ozawa, T., Morita, T., ... \& Takahashi, H. (2009). Depletion of medullary serotonergic neurons in patients with multiple system atrophy who succumbed to sudden death. Brain, 132(7), 1810-1819.

Titze, I. R. (2020). Inertagrams for a variety of semi-occluded vocal tracts. Journal of Speech, Language, and Hearing Research, 63(8), 2589-2596.

Titze, I. R. (2006). Theoretical analysis of maximum flow declination rate versus maximum area declination rate in phonation. Journal of Speech, Language, and Hearing Research, 49(2), 439-447.

Titze, I. R., \& Laukkanen, A. M. (2007). Can vocal economy in phonation be increased with an artificially lengthened vocal tract? a computer modeling study. Logopedics Phoniatrics Vocology, 32(4), 147-156.

Wakabayashi, K., Yoshimoto, M., Tsuji, S., \& Takahashi, H. (1998). a-Synuclein immunoreactivity in glial cytoplasmic inclusions in multiple system atrophy. Neuroscience letters, 249(2-3), 180-182.

Wang, Y., Shao, W. B., Gao, L., Lu, J., Gu, H., Sun, L. H., ... \& Zhang, Y. D. (2014). Abnormal pulmonary function and respiratory muscle strength findings in Chinese patients with Parkinson's disease and multiple system atrophy-comparison with normal elderly. PLoS One, 9(12), e116123.

Yu, M., Choi, S. H., Choi, C. H., \& Choi, B. (2018). Predicting normal and pathological voice using a cepstral based acoustic index in sustained vowels versus connected speech. Communication Sciences \& Disorders, 23(4), 1055-1064.

Zhu, X. Y., Pan, T. H., Ondo, W. G., Jimenez-Shahed, J., \& Wu, Y. C. (2014). Effects of deep brain stimulation in relatively young-onset multiple system atrophy Parkinsonism. Journal of the Neurological Sciences, 342(1-2), 4244. 


\section{국문초록}

\section{물저항 치료를 이용한 다계통위축증의 환자의 마비말장애 치료 효과}

채혜림 ${ }^{1}$ 최성희 ${ }^{1,2} \cdot$ 최철희 ${ }^{1,2}$

${ }^{1}$ 대구가톨릭대학교 일반대학원 언어청각치료학과, ${ }^{2}$ 대구가톨릭대학교 언어청각치료학과

배경 및 목적: 다계통위축증은 비정형 파킨슨 증후군으로 실조형과 경직형 및 과소 운동형의 혼합형 마비말장애이며, 호흡, 발성, 공명 및 조음에 영향을 준다. 하지만, 아직까지 다계통위축증 말치료에 대한 중재법이 매우 제한적이며 연구마다 치료 효과가 상이하다. 본 연구의 목적은 총체적 음성치료기법인 물저항 치료를 사용하여 다계통위축증 환자의 마비말장애 치료의 효과를 살펴보고자 한다. 방 법: 실조형 다계통위축증으로 진단받은 총 9명(남자 5명, 여자 4명)을 대상으로 물저항 치료를 주 1 회 간격으로 6주간 총 6회 실시하였 다. 치료 효과를 분석하기 위하여 치료 전후 공기역학적 및 음향학적, 청지각적 파라미터를 측정하였으며, 질병 진행 기간에 따른 치료 효과를 살펴보기 위하여 발병 후 4년 미만과 4년 이상 집단의 측정치를 비교하였다. 결과: 치료 후 공기역학적, 음향학적 및 청지각적 평 가에서 유의하게 개선되었다. 공기역학적 평가 결과, 폐활량, 최대발성지속시간, 호기량이 증가하고 성문하압이 감소하였다. 음향학적 평가 결과, Jitt, $\mathrm{PPQ}, \mathrm{sPPQ}, \mathrm{vF} 0$, Shim, $\mathrm{APQ}, \mathrm{sAPQ}, \mathrm{vAm}, \mathrm{STD}, \mathrm{NHR}, \sigma \mathrm{CPP}, \sigma \mathrm{L} / \mathrm{H}$ ratio가 감소하고 $\mathrm{CPP}, \mathrm{L} / \mathrm{H}$ ratio가 증가하였다. 청지 각적 평가에서는 거친 음성과 긴장되 쥐어짜는 음성, 음도 변이, 음성진전, 음소 연장, 말명료도가 개선되었다. 또한, 발병 초기 그룹은 $\mathrm{sAPQ}, \mathrm{vAm}, \sigma \mathrm{CPP}$, 발병 후기 그룹은 $\mathrm{APQ}$ 가 통계적으로 각각 유의한 차이가 있었다 $(p<.05)$. 논의 및 결론: 물저항 치료 후 다계통위 축증 환자의 호흡, 발성, 공명 및 조음 개선에 유의하게 긍정적인 효과가 나타났다. 물저항 치료는 다계통위축증 환자의 효과적인 마비 말장애 치료 방법으로 사용될 수 있을 것이다.

핵심어: 다계통위축증, 마비말장애, 물저항 음성치료, 치료 효과

\section{참고문헌}

Joseph R. Duffy (2013). 말운동장애: 기질·감별진단·중재 제3판(김향희, 서미경, 김윤정, 윤지혜 공역). 서울: 박학사.

김재옥(2014). KayPENTAX Phonatory Aerodynamic System Model 6600을 이용한 한국 성인의 공기역학적 변수들의 정상치. 말소리와 음성과학, 6(1), 105-117.

김향희, 이미숙, 김선우, 최성희, 이원용(2004). 파킨슨증으로 인한 마비말장애에 대한 청지각적 평가척도. 음성과학, 11(2), 39-49.

박영미(2018). 다계통위축증 환자를 대상으로 한 마비말장애 집중 치료의 효과. 말소리와음성과학, 10(4), 163-171.

유미옥, 최성희, 최철희, 최병흔(2018). 모음과 연결발화에서 캡스트럼 음향 지표의 정상 및 음성장애 예측. Communication Sciences \& Disorder,

23(4), 1055-1064.

이승진, 표화영, 최홍식(2018). 모음 발성 및 문단 읽기 과제 시 한국 성인의 켑스트럼 및 스펙트럼 측정치 정상 규준 연구. Communication Sciences

\&Disorder, 23(1), 208-217.

채혜림, 최성희, 최철희, 이경재(2019). Lax Vox 음성치료가 파킨슨병 환자의 호흡 및 발성에 미치는 효과. Communication Sciences \& Disorder,

24(3), 785-799.

최성희(2017). 공연예술가를 위한 반폐쇄성도훈련: 악센트기법, 빨대 발성, Lax Vox. 한국공연예술발성연구회지, 4, 11-19.

최성희(2018). 음성장애 환자의 음질 평가를 위한 표준문장 개발. Audiology and Speech Research, 14(2), 128-142.

최성희, 최철희(2016). 한국 정상 화자의 캡스트럼과 스펙트럼 측정치의 성별과 발화 과제 효과. Audiology and Speech Research, 12(3), 157-163.

\section{ORCID}

채혜림(제1저자, 대학원생 https://orcid.org/0000-0002-9088-5425); 최성희(교신저자, 교수 https://orcid.org/0000-0003-2365-6187); 최철희(공동저자, 교수 https://orcid.org/0000-0003-1844-3072) 